\title{
Methods for the Assessment of Critical Properties in Existing Masonry Structures under Seismic Loads-The ARES Project
}

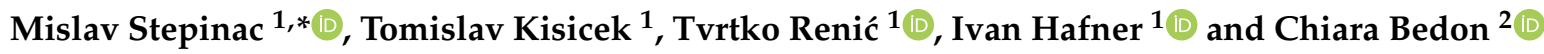 \\ 1 Faculty of Civil Engineering, University of Zagreb, 10000 Zagreb, Croatia; \\ tomislav.kisicek@grad.unizg.hr (T.K.); tvrtko.renic@grad.unizg.hr (T.R.); ivan.hafner@grad.unizg.hr (I.H.) \\ 2 Department of Engineering and Architecture, University of Trieste, 34127 Trieste, Italy; \\ chiara.bedon@dia.units.it \\ * Correspondence: mislav.stepinac@grad.unizg.hr
}

Received: 12 December 2019; Accepted: 19 February 2020; Published: 25 February 2020

\begin{abstract}
Masonry structures are notoriously vulnerable to horizontal actions caused by earthquakes. Given the high seismicity of the European region, and that the European building stock comprises a lot of masonry buildings, knowledge about their structural response to seismic excitation is particularly important, but at the same time difficult to determine, due to the heterogenous nature of materials and/or constructional techniques in use. An additional issue is represented by the current methods for mechanical properties assessment, that do not provide a reliable framework for accurate structural estimations of existing buildings characterized by different typological properties. Every structure, in other words, should be separately inspected in regard to its mechanical behaviour, based on dedicated approaches able to capture potential critical issues. In this review paper, an insight on the Croatian ARES project is presented (Assessment and Rehabilitation of Existing Structures), including a state-of-the-art of the actual building stock and giving evidence of major difficulties concerning the assessment of existing structures. The most commonly used techniques and tools are compared, with a focus on their basic features and field of application. A brief overview of prevailing structural behaviours and Finite Element numerical modelling issues are also mentioned. As shown, the general tendency is to ensure "sustainable" and energy-efficient building systems. The latter, however, seem in disagreement with basic principles of structural maintenance and renovation. The aim of the ongoing ARES project, in this context, is to improve the current knowledge regarding the assessment and strengthening of structures, with a focus on a more reliable design and maintenance process for existing masonry buildings.
\end{abstract}

Keywords: structural assessment; masonry buildings; earthquakes; seismic loads; existing structures; reliability; rehabilitation; risk

\section{Introduction}

According to the literature and recent events, it is well established that masonry is one of the most commonly used materials across the world, due to its simplicity and high quality characteristics.

Even though the use of masonry for construction in earthquake-prone regions gave evidence of its intrinsic limitations (due especially to its limited tensile resistance, relevant mass and stiffness), extensive research has been carried out in the last few decades, with a focus on the material characteristics and structural behaviour, even under extreme loading conditions such as earthquake events. These efforts enabled engineers to design masonry structures on sound and safety principles, with progressively greater exactitude, economy and confidence. Accordingly, a huge number of existing buildings in the 
European region are composed of masonry. Given that most of the so-called "strategic" buildings of cultural significance and high historical importance are built using masonry, such a condition is the first motivation, suggesting that the assessment and rehabilitation of existing masonry structures must be conducted on a very high level.

As is known, the main goal of seismic design is to protect property-and thus life in buildings and infrastructure-in the case of earthquake events. However, an appropriate seismic design approach must necessarily develop on knowledge and feedback from existing structures. Compared to other constructional typologies and materials, past events showed that seismic loads usually cause significant damage, especially in masonry buildings, due to their large mass and stiffness. This represents an intrinsic risk for personnel, given that most people in several European countries (especially in the urban areas) work and live in masonry buildings. In addition, a huge number of masonry structures were built—over decades—before any seismic codes were developed, thus no confining elements or reinforcement members exist.

Based on all the above motivations, it is thus clear that a concise strategy for masonry buildings must be activated.

The seismic behaviour of buildings generally depends on several important factors, such as material properties, the geometry of the structure, additional non-linear effects, conceptual design and stiffness properties. The issue of seismic vulnerability assessment and rehabilitation of under-performing existing buildings is hence a complex problem [1]. "Seismic vulnerability" can be conventionally defined as a measure of the inadequacy of a given structure to resist to seismic actions [2]. In modern assessment methods, the seismic vulnerability is represented by design curves which express the physical vulnerability as a function of the intensity of the process and the degree of loss [3]. For individual cases only, some structural characteristics of the affected buildings are considered [3]. Throughout the decades, various methods have been developed to evaluate the vulnerability of buildings, and they can be divided into empirical and analytical (and thus hybrid) methods, and an approach based on engineering judgment by experts. Methods for vulnerability assessments mainly model damage to a discrete scale, where damage itself is commonly grouped using three to six categories [4]. However, no unified approaches on a European level are available.

The seismic vulnerability of masonry buildings is particularly difficult to assess, and notoriously requires a multitude of specialized technical skills [5]. But actually, how accurate are the methods in use for the assessment of the seismic vulnerability of existing buildings?

Unfortunately, this question generally remains unanswered, given that more extended research needs to be carried out on the topics of seismic risk and seismic vulnerability assessment. Focusing only on "visible" structural/material parameters cannot solve such an open issue. Traditional assessment methods, in most of the cases, are in fact well-known to allow the assessment of only the actual condition of a given existing structure, once its stability has already been compromised. In this paper, selected traditional assessment methods are thus discussed, pointing out some possibilities related to the use of newer technologies.

The surge of buildings of higher consequence class (and the global goals towards sustainable development) typically demands higher levels of reliability, and a more sustainable use of raw materials. That is why it the aim is the modification or extension of existing buildings rather than the demolition and substitution. There are several important aspects that have a fundamental role in the assessment of existing masonry structures, namely assessment, deterioration and damage, inspection and investigation, updating, verification, repair, rehabilitation and reinforcement and maintenance. In this paper, assessment methods of critical properties (structural and material parameters) are presented for masonry structures. A focus is set on the available methods able to provide crucial data and feedback for preventing failure mechanisms and collapses under extreme design loads. 


\section{The Croatian Scenario}

According to the results of systematic research of Statistical Yearbooks, Croatia's national building stock consists of approx. 800,000 residential and 125,000 non-residential buildings [6]. More than 75\% of the building stock is older than 30 years, thus corresponding to a life-time requiring at least some renovation or modification of primary structural components. More than $40 \%$ of the building stock is then older than 50 years, meaning that the service life of a given structure is fully expired. In the Croatian building sector, finally, it is recognized that up to $40 \%$ of the expenses are dedicated to the rehabilitation, modification and demolition of existing structures (Figure 1a).

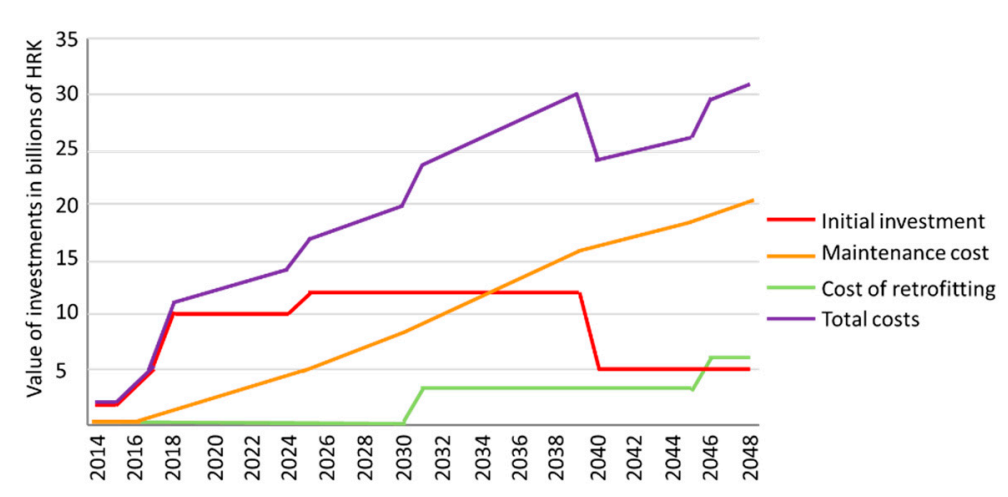

(a)

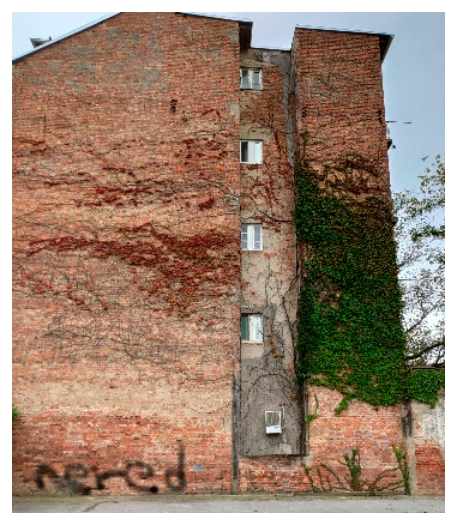

(b)

Figure 1. (a) Investment (values in HRK) for the renovation of Croatian national building stock (data derived from [6]); (b) Typical masonry building in Zagreb, with a graffiti meaning "a mess" (photo by M. Stepinac).

The main characteristic of Croatian buildings constructed in the period before the 1970s is represented by the use of traditional constructional techniques and materials, such as masonry and timber (Figure 1b). Buildings were built as full-brick masonry structures, with mostly wooden ceilings, and 30-60 cm thick walls, thus resulting in statically satisfactory structural assemblies. In the 1960s, reinforced concrete (in combination with timber and steel) started to progressively replace traditional constructional materials. In fact, most of the residential structures are still built as a combination of concrete, masonry and timber load-bearing components.

One of the most important HORIZON 2020 programme objectives is the acquisition of necessary knowledge and skills by all stakeholders in the process of energy-efficient building renovation. European Union directives clearly suggest the energy renovation of existing structures, but structural aspects are somewhat ignored and/or disregarded. At the moment, a number of existing structures are in fact under energy renovation and/or energy upgrading processes (Figure 2a). Besides such a consideration for energy performances, however, structural assessment and/or structural upgrading is mostly disregarded. According to an estimate of total investments in Europe, for the period between 2014 and 2049 (including initial investment expenditures, maintenance and replacement of worn-out equipment), around $3 \times 10^{9}$ Euros will be dedicated to energy processes. In such an expected scenario, it is thus clear that structural updating and retrofitting can (and must) represent an additional value for the energy renovation of buildings. This is especially the case in existing masonry structures, which, in most cases, need robust seismic strengthening interventions.

In the Croatian framework, it is in fact recognized that the majority of residential buildings older than 50 years consists of masonry structures (i.e., Figure $2 \mathrm{~b}$ ) without appropriate bonding elements to connect floors and walls [7]. 


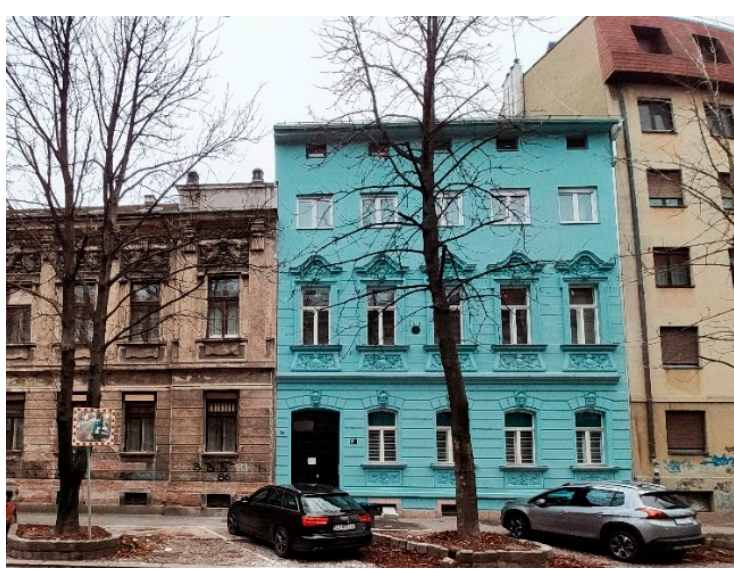

(a)

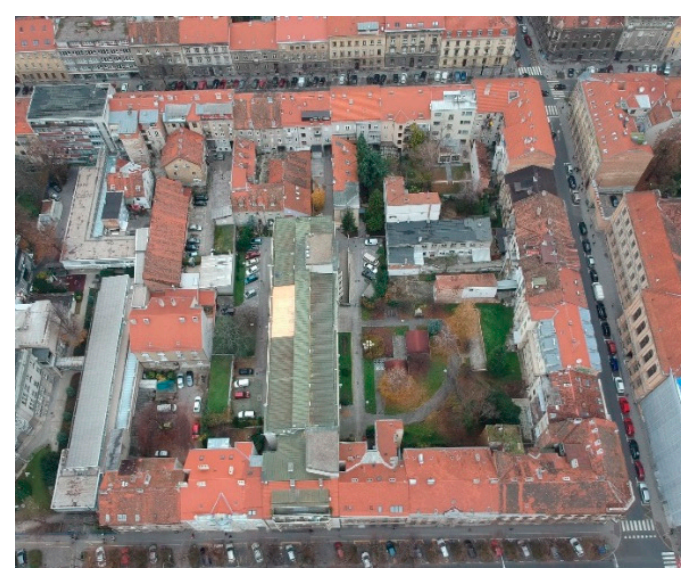

(b)

Figure 2. (a) Renovation of facades and energy upgrading of existing structures (b) Typical building blocks in Zagreb (photos by M. Stepinac).

\section{Existing Masonry Structures and Maintenance Issues}

The need for maintaining the built environment is supported by the global policy of the Kyoto protocol 1997 and all further World Climate Summits on existing buildings and engineering works. Sustainable development is a long-term goal of the global policy which results in modifications, substitutions or extensions of existing buildings.

In simple words, existing structures can be distinguished with regard to their value between economical (monetary) values and cultural (non-material) value. Modern existing structures commonly have a higher economical value, compared to heritage structures (with a dominating cultural value).

Accordingly, the assessment of an existing structure can be performed through different steps, with increased precision. The degree of precision thereby depends on the amount and on the quality of available information, as well as on the importance of the building being assessed. This can be reached by breaking down the assessment into different phases. The number of required phases is dependent on the remaining level of doubt, and the feasibility and simplicity of repair/strengthening, always in combination with economic considerations [8].

Advances in technology and sustainability requirements, and requirements for preservation of existing structures provoked an increased interest in scientific and professional community for assessment methods. Regarding the masonry structures, a wide variety of methods exist'; however, their frequency and scope, the decision-making approach concerning safety and the necessary interventions are far from being agreed upon. The need for an assessment of an existing structure can be based upon a multitude of reasons. The most typical are briefly explained in [8]. In situations where doubts may be raised in regard to the design assumptions, a re-assessment of the structure may be also necessary, such as $[9,10]$ :

- extended service life;

- change in utilization;

- required increase in the level of reliability;

- lack of maintenance and inspection for an extended period;

- doubts regarding the reliability or malfunctioning of the structure (e.g., inadequate serviceability);

- exposure to accidental or unforeseen extreme loads (excessive loading, earthquake, fire, etc.);

- negative experience from other similar structures;

- availability of new knowledge and revised design codes;

- knowledge of errors in the planning or construction period.

With regard to economy and sustainability, finally, it is certainly of high interest for the building owners (as well as society) to maintain existing structures, rather than demolish and rebuild them. 


\section{European Standards, Norms and Guidelines}

Most of the current design standards and guidelines are based on reliability-based design, as specified in ISO 2394 [11] or JCSS [12] documents. The majority of them regulate the design of new structures, such as the Eurocodes. Nevertheless, the intention is to make the Eurocodes applicable also for existing structures. Work on new technical rules for the assessment and retrofitting of existing structures is currently very intense, with special attention being given to heritage structures, aiming at elaborating the new Eurocode part for existing structures.

One of the few international guidelines for the assessment of existing structures is the ISO 13822 document [13]. Although different guidelines for the maintenance of existing structures exist in other European countries, only a few of them have issued standards for the assessment of existing structures (e.g., Switzerland [14] and the Netherlands [15]). More in detail, SIA 462 [14] standard, in combination with the SIA 469 [16] document, specify the general fundamentals for the assessment of the load-carrying capacity of existing buildings, and regulate the professional and economical maintenance of buildings according to their cultural value, respectively.

Nonetheless, the daily basis for the assessment and rehabilitation of existing structures is still based on a rather rudimentary scheme, mainly replacing and reinforcing defective members. More sophisticated procedures are needed, in addition to those available in seismic codes (such as Eurocodes). Eurocode EN 1998-3 [17] provides some suggestions for the assessment of masonry structures, but it is only informative and lacks of detailed practical suggestions. ISO 13822:2010 [13] gives general recommendations for a rough assessment of existing structures, but does not take materials into account. Similar to EN 1998-3 [17], it is mainly informative and lacks depth. Neither of these standards are very practical. The American documents ASCE 41-13 [18,19] and ASTM [20-25], in this regard, constitute a more comprehensive guide, including suggested equipment, procedures of assessment, number of tests, as well as analysis and strength calculation methods. From the perspective of an engineer, this standard is hence more practical and easily applicable.

\section{Selected Assessment Methods}

Numerous technical documents have been published by national and international authorities and focus on systematic and scientific methods that can be used to accurately assess the residual strength, durability and reliability of structural materials, assemblies and systems in existing buildings. Nevertheless, especially in the scope of masonry structures, all these documents need to be continuously revised, expanded and enhanced. Major issues are related to the increasing knowledge in the field of material sciences, as well as to the technological advancement in the field of the structural assessment and monitoring of structural systems, or to the practical experience and feedback derived from professional engineering activities on existing structures. The key role and relevance of research, in this context, lays in the preservation of existing building stock, restoration of objects, towards the support and development of reliable and consistent guidelines/norms.

Masonry structures are composite systems, whose main components are masonry units and mortar layers. Both can be made of various materials, with different mechanical characteristics. The geometry of masonry units (length, width, height, amount and direction of holes), the thickness of mortar and the area it covers can also strongly affect the overall mechanical behaviour. Recent research studies have shown that the inclusion of masonry infills leads to a significant increase in structural stiffness, thus affecting the overall probability of structural collapse under dynamic loads (such as those induced during an earthquake). Specifications of compressive strength, a function of parameters of brick and mortar, are often required. Assessing the variability of these properties and the uncertainty in the modelling of the masonry compressive strength is hence a topic of great importance [26].

For the assessment of existing structures, the strength classes of used materials are often unknown. Nevertheless, major advantage and benefit can derive from the fact that the reliability of structures directly depends on the actual properties of the elements in use. Assessment methods should therefore aim at identifying these properties to the highest degree of achievable certainty, in order to reduce the 
uncertainty with regard to the resistance of the structure as a whole. In contrast, for the design of new structures, possible uncertainties on material properties are taken into account in the partial safety factors for strength properties.

Parameters which are always measured when assessing masonry structures are thus represented by (i) the compressive strength of masonry units, (ii) the compressive strength of masonry mortar, (iii) the compressive strength of concrete infill (if any), (iv) the strength of reinforcing steel bars (if any), (v) the compressive, shear and flexural strength of masonry, (vi) the Modulus of Elasticity (MoE) and the geometry of the masonry structure (size and location of bearing walls, location and size of openings).

The most important Non Destructive Testing (NDT) methods for existing masonry structures are summarized in Table 1 and Figures 3 and 4.

Table 1. Available Non Destructive Testing (NDT) assessment methods for existing masonry structures.

\begin{tabular}{|c|c|c|c|c|}
\hline NDT Method & Devices/Test & What Is Measured? & How Is It Measured? & References \\
\hline $\begin{array}{l}\text { Visual } \\
\text { inspection }\end{array}$ & / & $\begin{array}{l}\text { Quality of masonry } \\
\text { (mechanical parameters, } \\
\text { dimension, shape), } \\
\text { mortar and wall } \\
\text { connections }\end{array}$ & $\begin{array}{l}\text { Without a device, using a } \\
\text { base/set of rules (i.e., Masonry } \\
\text { quality index-MQI) }\end{array}$ & Borri et al. [27] \\
\hline $\begin{array}{l}\text { Measurement of } \\
\text { masonry unit } \\
\text { hardness }\end{array}$ & $\begin{array}{l}\text { Rebound hammer } \\
\text { (Schmidt hammer) }\end{array}$ & $\begin{array}{l}\text { Compressive strength of } \\
\text { masonry units, mortars } \\
\text { and built masonry }\end{array}$ & $\begin{array}{l}\text { A predefined number of tests is } \\
\text { conducted in both horizontal } \\
\text { and vertical direction (with a } \\
\text { calibration needed) }\end{array}$ & $\begin{array}{l}\text { Breysse and } \\
\text { Martínez- } \\
\text { Fernández [28], } \\
\text { Sýkora et al. [29] }\end{array}$ \\
\hline $\begin{array}{l}\text { Measurement of } \\
\text { reinforcement } \\
\text { location }\end{array}$ & $\begin{array}{l}\text { Ground } \\
\text { Penetrating Radar } \\
(\text { GPR })\end{array}$ & $\begin{array}{l}\text { Location (depth) of } \\
\text { reinforcement }\end{array}$ & $\begin{array}{l}\text { The device is placed on the } \\
\text { measured surface and moved } \\
\text { along a linear axis (with a } \\
\text { calibration needed), } \\
\text { transmitting radio wave signals } \\
\text { into a structure and detecting } \\
\text { echoes }\end{array}$ & $\begin{array}{l}\text { Agred, Klysz } \\
\text { and Balayssac } \\
\text { [30] }\end{array}$ \\
\hline $\begin{array}{l}\text { Stress wave } \\
\text { transmission }\end{array}$ & $\begin{array}{l}\text { Ultrasonic Pulse } \\
\text { Velocity test (UPV) } \\
\text { test/Resonant } \\
\text { frequency test } \\
(\mathrm{RF})\end{array}$ & $\begin{array}{l}\text { Compressive strength of } \\
\text { concrete or masonry }\end{array}$ & $\begin{array}{l}\text { UPV-two transducers are placed } \\
\text { on two sides of the specimen } \\
\text { after which the time of wave } \\
\text { travel is measured RF-a } \\
\text { piezometric sensor is used with } \\
\text { different attachment techniques } \\
\text { to obtain resonant frequency }\end{array}$ & Sajid et al. [31] \\
\hline $\begin{array}{l}\text { Ultrasonic } \\
\text { velocity testing }\end{array}$ & $\begin{array}{l}\text { Impact hammer } \\
\text { and accelerometer }\end{array}$ & $\begin{array}{l}\text { Characterization of } \\
\text { masonry wall } \\
\text { homogeneity and } \\
\text { variability }\end{array}$ & $\begin{array}{l}\text { On opposite sides of the wall, an } \\
\text { impact hammer and an } \\
\text { accelerometer are placed. The } \\
\text { mechanical impulse is generated } \\
\text { by the hammer striking the } \\
\text { material and the signal is then } \\
\text { received by the accelerometer. }\end{array}$ & $\begin{array}{l}\text { Mesquita et al. } \\
\text { [32] }\end{array}$ \\
\hline $\begin{array}{l}\text { Sonic velocity } \\
\text { testing }\end{array}$ & $\begin{array}{l}\text { Impact hammer } \\
\text { and accelerometer }\end{array}$ & $\begin{array}{l}\text { Location of } \\
\text { heterogeneities, voids or } \\
\text { inclusions of other } \\
\text { materials in masonry } \\
\text { elements }\end{array}$ & $\begin{array}{l}\text { On opposite sides of the wall, an } \\
\text { impact hammer and an } \\
\text { accelerometer are placed, after } \\
\text { which the mechanical impulse is } \\
\text { generated by the hammer } \\
\text { striking the material and the } \\
\text { signal is then received by the } \\
\text { accelerometer }\end{array}$ & $\begin{array}{l}\text { Martini et al. } \\
\text { [33] } \\
\text { Valluzzi et al. } \\
\text { [34] }\end{array}$ \\
\hline $\begin{array}{l}\text { Surface } \\
\text { penetrating } \\
\text { radar }\end{array}$ & $\begin{array}{l}\text { Ground } \\
\text { Penetrating Radar } \\
(\mathrm{GPR})\end{array}$ & $\begin{array}{l}\text { Location (depth) of } \\
\text { reinforcement, thickness } \\
\text { of elements, position of } \\
\text { voids and moisture } \\
\text { content }\end{array}$ & $\begin{array}{l}\text { The device is placed on the } \\
\text { measured surface and moved } \\
\text { along a linear axis (with a } \\
\text { calibration needed) transmitting } \\
\text { radio wave signals into a } \\
\text { structure and detecting echoes }\end{array}$ & $\begin{array}{l}\text { Martini et al. } \\
\text { [33] } \\
\text { Wai-Lok Lai, } \\
\text { Dérobert and } \\
\text { Annan [35] }\end{array}$ \\
\hline
\end{tabular}


Table 1. Cont.

\begin{tabular}{|c|c|c|c|c|}
\hline NDT Method & Devices/Test & What Is Measured? & How Is It Measured? & References \\
\hline $\begin{array}{l}\text { Infrared } \\
\text { thermography }\end{array}$ & $\begin{array}{l}\text { Thermography } \\
\text { cameras } \\
\text { Visual IR } \\
\text { thermometers }\end{array}$ & $\begin{array}{l}\text { Defects in the buildings } \\
\text { envelope, the monitoring } \\
\text { of reinforcing steel in } \\
\text { concrete, the detection of } \\
\text { moisture etc. }\end{array}$ & $\begin{array}{l}\text { The specimen is under thermal } \\
\text { stimulation and its surface } \\
\text { temperature variation is } \\
\text { monitored during the heating or } \\
\text { cooling phase (the presence of } \\
\text { inhomogeneity in a material } \\
\text { causes local temperature } \\
\text { variations) }\end{array}$ & Meola [36] \\
\hline $\begin{array}{l}\text { Borescope and } \\
\text { mortar hardness } \\
\text { with pendulum } \\
\text { rebound } \\
\text { hammer }\end{array}$ & $\begin{array}{l}\text { Borescope and } \\
\text { pendulum } \\
\text { rebound hammer }\end{array}$ & $\begin{array}{l}\text { Borescope-anomalies } \\
\text { and internal wall } \\
\text { components, such as ties, } \\
\text { flashing and drainage } \\
\text { cavities } \\
\text { Pendulum rebound } \\
\text { hammer-mortar type } \\
\text { and strength }\end{array}$ & $\begin{array}{l}\text { The borescope is inserted into } \\
\text { small holes drilled into mortar } \\
\text { joints (with fiber optics and } \\
\text { internal light source) } \\
\text { The pendulum rebound hammer } \\
\text { utilizes a low energy impact and } \\
\text { the resulting rebound from the } \\
\text { surface of a mortar joint is used } \\
\text { to measure surface hardness }\end{array}$ & Schuller [37] \\
\hline Flat-jack tests & Flat jacks & $\begin{array}{l}\text { Deformability parameters } \\
\text { in compression, } \\
\text { compressive strength and } \\
\text { shear strength parameters }\end{array}$ & $\begin{array}{l}\text { Two cuts are made with a } \\
\text { predefined distance between } \\
\text { them (horizontal cuts for } \\
\text { compression, vertical cuts for } \\
\text { shear), after which the jack is } \\
\text { inflated with a liquid that } \\
\text { transmits hydrostatic pressure }\end{array}$ & $\begin{array}{l}\text { Parivallal et al. } \\
\text { [38], Simões et al. } \\
\text { [39], Łatka and } \\
\text { Matysek [40], } \\
\text { Croce et al. [41] }\end{array}$ \\
\hline $\begin{array}{l}\text { Acoustic } \\
\text { emission }\end{array}$ & & $\begin{array}{l}\text { The damage evolution in } \\
\text { masonry, evaluation of } \\
\text { the reliability of } \\
\text { reinforcing techniques, } \\
\text { analysis of residual } \\
\text { capacity of brick masonry }\end{array}$ & $\begin{array}{l}\text { A group of transducers are set to } \\
\text { record signals, then locate the } \\
\text { precise area of their origin by } \\
\text { measuring the time for the } \\
\text { sound to reach different } \\
\text { transducers. }\end{array}$ & $\begin{array}{l}\text { Invernizzi et al. } \\
\text { [42] }\end{array}$ \\
\hline
\end{tabular}

Although each method mentioned in Table 1 has both advantages and disadvantages, not all of them are needed for adequate assessment. For an adequate assessment, further methods may be applied (although other combinations are possible).

Visual inspection presents a basic tool for the assessment of existing buildings. It is a significant method which should always be implemented to determine further actions. The type of masonry, building location specifics and overall state of the structure can be determined and rough estimations may be made. One of the negatives is that it requires an experienced person to determine the important parameters.

A rebound hammer is a tool that may be used to indirectly determine the compressive strength of masonry. Since this is one of the most important parameters and considering both its low cost and ease of applicability, this method seems to be a valuable tool. Although some methods may be better at determining compressive strength, they are either more expensive and complex, or not non-destructive.

Ground penetrating radar can detect the location of steel, thickness of the wall and possible voids in it. It is a versatile tool with which the geometry of a wall can be determined precisely.

Flat-jack systems can be used to assess the stresses in existing walls, strength and deformability parameters, as well as shear strength of a wall. These are all important values to obtain for a more precise assessment. One of the downsides is the fact that slits need to be cut in a wall. Either rigid or flexible flat-jacks can be used, depending on the type of wall that is being tested.

In addition to assessment, continuous Structural Health Monitoring (SHM) may assist engineers for a better understanding of the actual structural behaviour of a given assembly. Together with structural risk and reliability research and development, SHM specialists figure a comprehensive research community. Accordingly, it is generally recognized that SHM represents an important field of today's infrastructure engineering. It is a goal to enhance the benefit of SHM by the novel utilization of applied decision analysis on how to assess the value of SHM-even before it is implemented. 

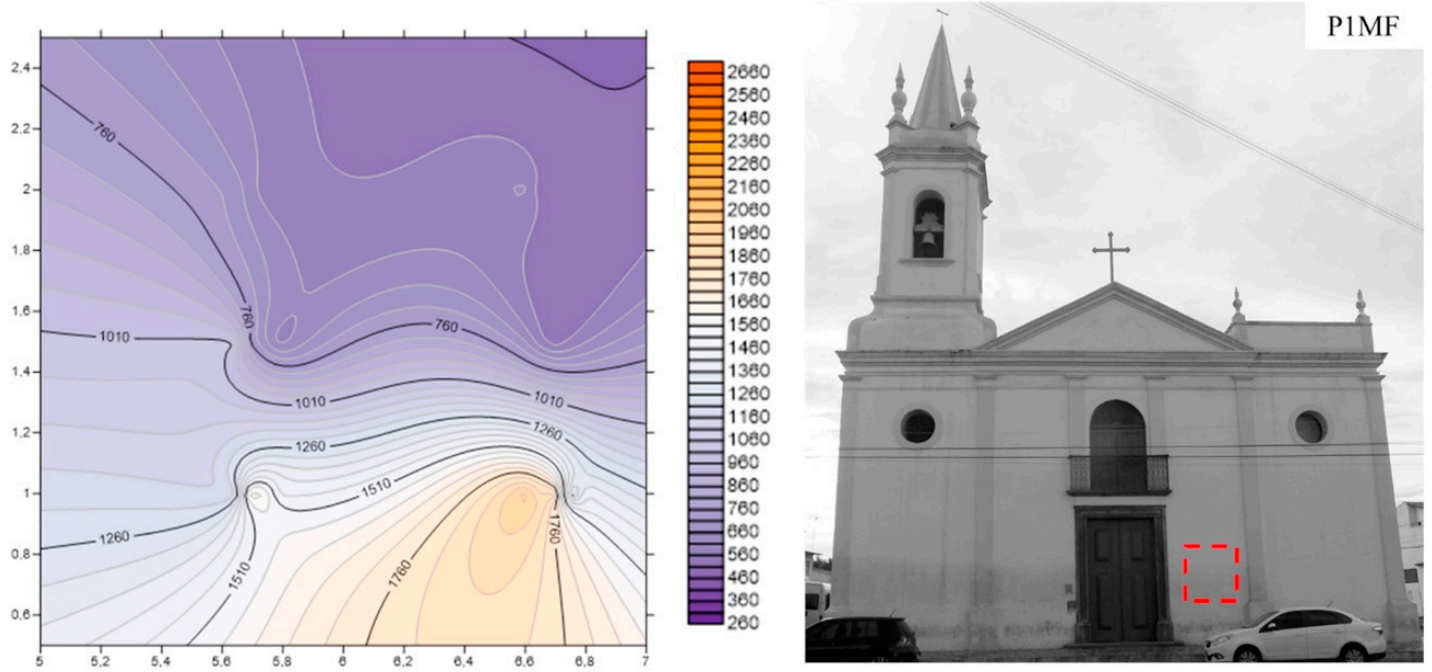

Figure 3. Example of ultrasonic velocities distribution (values in $\mathrm{m} / \mathrm{s}$ ) for a portion of the "P1MF" case-study building (box detail). Reproduced from [25] with permission from Elsevier ${ }^{\circledR}$ (Copyright $($ ) Agreement license n. 4726430416591, December 2019).
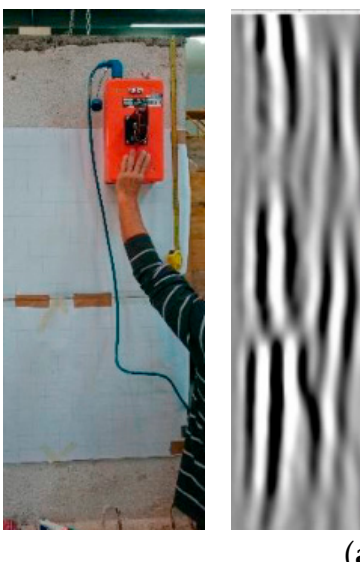

(a)

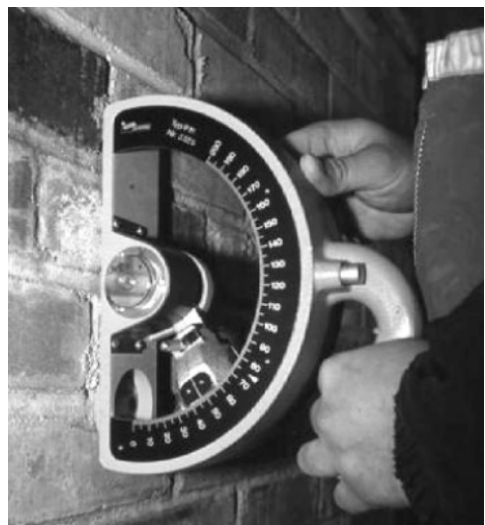

(b)
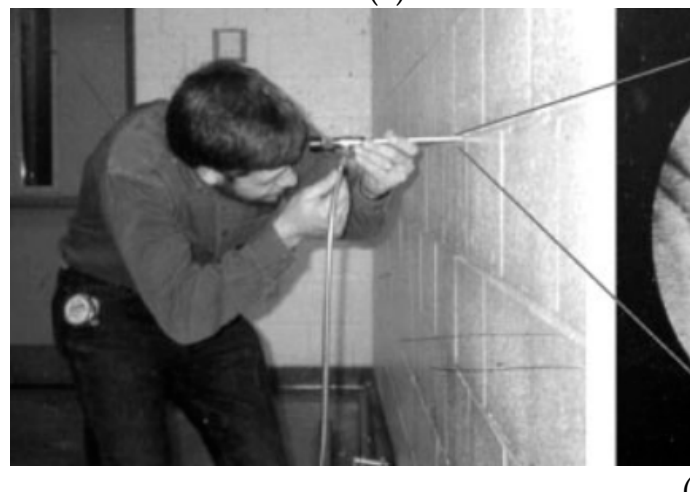

(c)

Figure 4. Example of NDT assessment of existing masonry: (a) GPR testing instruments and results (reproduced from [27] with permission from Elsevier ${ }^{\circledR}$ (Copyright $($ ) Agreement license $n$. 4726440628105, December 2019)); (b) pendulum rebound hammer, to evaluate masonry hardness; with (c) borescope investigation (figures $(\mathbf{b}, \mathbf{c})$ are reproduced from [31] with permission from John Wiley \& Sons ${ }^{\circledR}$ (Copyright $\subset$ Agreement license n. 4726520295075, December 2019)).

Knowing the intrinsic value of SHM techniques, the decision basis for the design, operation and life-cycle integrity management of structures can thus be improved and can finally facilitate more cost-efficient, reliable and safe strategies for maintaining and developing the built environment to the 
benefit of society [43]. All of the above-mentioned methods (see also Figure 5) are in fact eligible to offer support for better understanding the structural behaviour, risks and costs for the preservation of existing masonry structures.

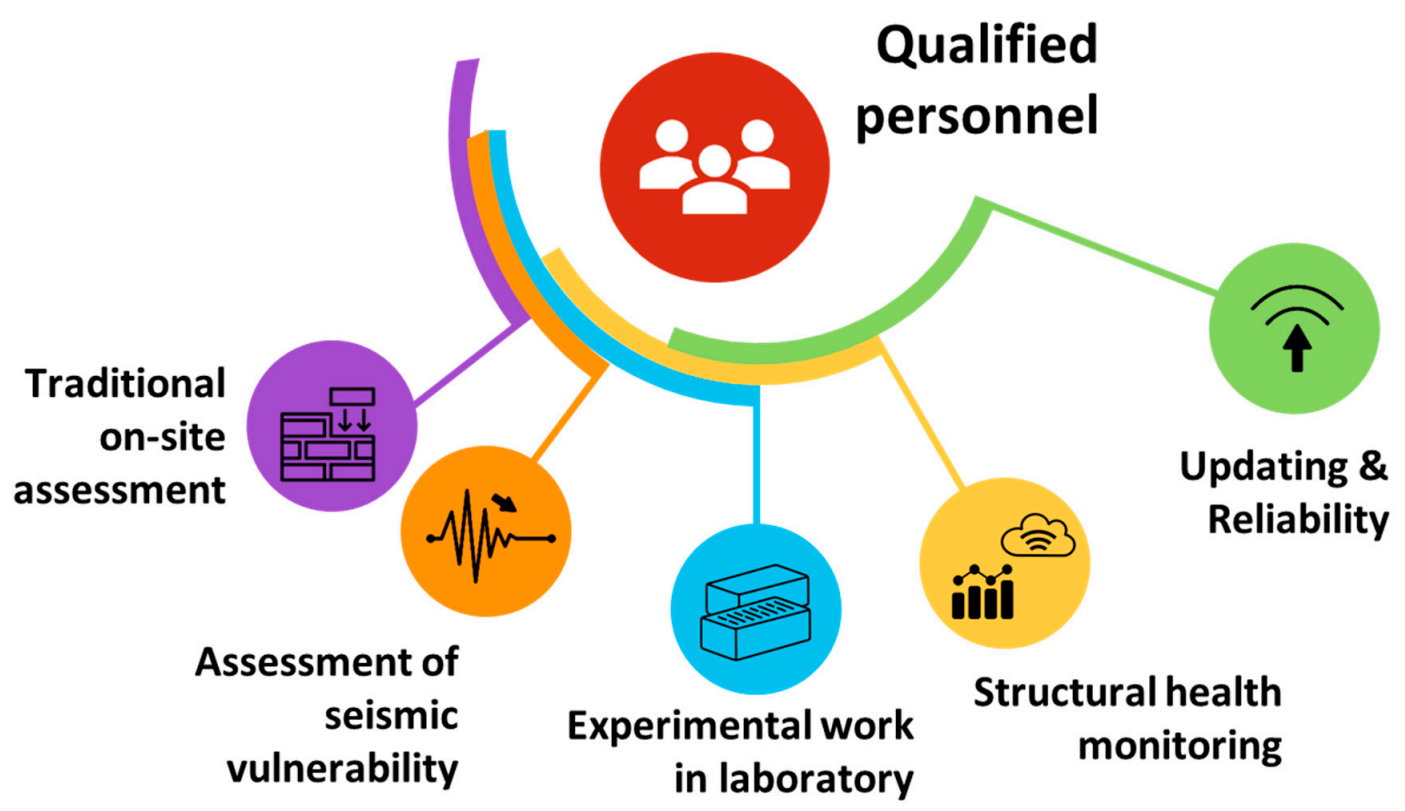

Figure 5. Graphical illustration of the typical assessment procedures for masonry structures.

\section{Seismic Actions and Masonry Structures}

In order to strengthen existing weak structures, assessment must be necessarily designed and carried out. In the past, most of the initial work on seismic assessment was based only on the visual inspection of buildings [27], NDT methods (see, for example, [32,41,44-46]), as well as the experience of engineers. The last decade, however, has seen a growth in the technological development of various tools which can greatly support the prediction of structural safety and seismic behaviour of existing structures, i.e., thermography [36], photogrammetry [47], unmanned aerial vehicles [48], etc.

The first key step is visual inspection. A structure's location, both in respect to seismic hazards [49] and with respect to micro-location (e.g., hill, valley, etc.) matters. Neighbouring structures can also influence structural behaviour. For example, different storey heights may lead to the collision of a slab with a neighbouring structure, as can be seen in Figure 6a.

While newer buildings tend to have lower stories than old buildings, this is not uncommon when a new structure is built inside a block of existing structures. Even if their storey height is the same, neighbouring structures, according to Figure $6 b$, may also collide.

The layout of a building's structural element defines its dynamic response, so it should be adequately measured or characterized [50]. It is not uncommon that access to the inside of a building is restricted. The time of construction can also represent another valuable piece of information, since it gives insight into the most probable material characteristics (both masonry units and mortar), used building technology and design codes. In terms of floor systems, the most commonly used solutions are timber in older constructions and reinforced concrete in newer constructions. Timber floors, as is known, are more flexible than stiff concrete slabs. This not only leads to a different distribution of seismic actions, but also means that walls are more susceptible to potential out-of-plane failure mechanisms. Concrete slabs are, in fact, recognized to ensure a box-type behaviour of walls. In structures with timber floors, horizontal steel rods are usually added to connect the walls (when they do not already exist) and overcome such an issue.

Besides the need of such a box-type behaviour and interlocking effect, the mortar and masonry quality of load-bearing elements typically degrades with time. Since different materials were used in 
history, it is advantageous to know the time period of construction. In addition, visual inspection of material degradation should be necessarily performed. From visual inspection, the position, direction and width of cracks can be measured and can indicate weak spots in a given structure, as well as poor soil conditions, or poor craftsmanship. In some cases, cracks may also be structurally negligible. The geometry of a wall, as well as shape, size and position of openings, can significantly influence crack formation and propagation. Cracks cause a reduction in stiffness, which in turn changes the dynamic response of a structure. To adequately model stiffness, the MoE needs to be known, which can be done with a flat-jack system or rebound hammer. Since stiffness distribution is also relevant, measurements should be done on all walls. When stiffness is correctly assessed, seismic forces can be determined. In order to check if a failure will occur, the strength of a material is needed. Compressive strength can be appraised (with careful laboratory calibration) by using the rebound hammer, which measures wall hardness. If reinforcement exists, its distribution and amount influence the crack width. Usually, reinforcement cannot be detected by visual inspection, so additional tools like Ground Penetrating Radar (GPR) are needed. Some of the reinforcement might be corroded or poorly anchored, and such an issue should be properly checked. Other important parameters of a wall can be assessed with GPR, such as the thickness of each wythe and a complete wall, or void location and size. Poor connection between different wythes may cause the falling out of a part of wall, which can potentially be dangerous for personnel. The dynamic response of a structure should be then properly checked using a Finite Element (FE) model. In the latter, however, the previously measured material parameters (or appraised on-site) should be carefully calibrated.

In addition to previously mentioned data, an important role is also that of soil, whose stiffness and strength should be carefully taken into account. The variation of soil conditions under the building should also be considered. Based on a structural model, stresses and strains may be calculated in each point of a wall. The vulnerability of a structure under different earthquake records may also be calculated and, in combination with hazard risk, can be defined. Based on risk, expected cost can be estimated. When the expected risk is unacceptable, the structure should be properly strengthened. This can be done by adding steel reinforcement or some sort of non-metallic material with high tensile resistance, such as Fiber-Reinforced Polymers (FRP) or Textile Reinforced Mortar (TRM) solutions. Based on the expected critical failure mechanisms, different configurations of reinforcement may be adopted. Strengthening can also be effective if maximum deformations either cause the failure of non-load-bearing elements or stability problems. Since stiffness changes with adding reinforcement, however, additional changes in the reference models should be necessarily implemented.

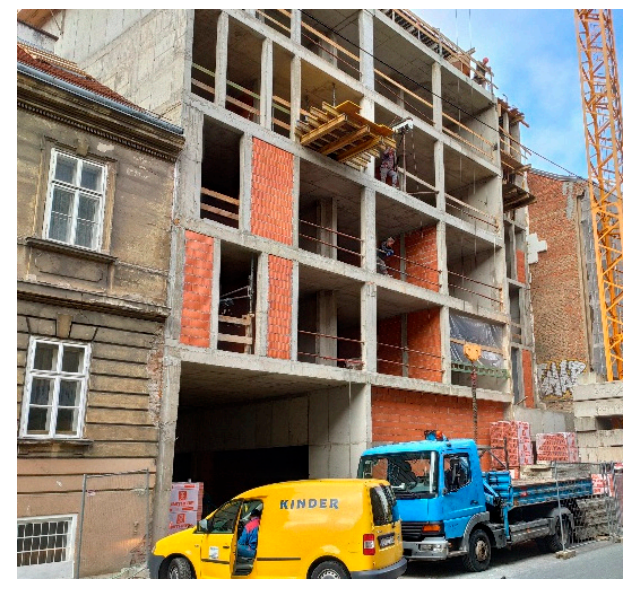

(a)

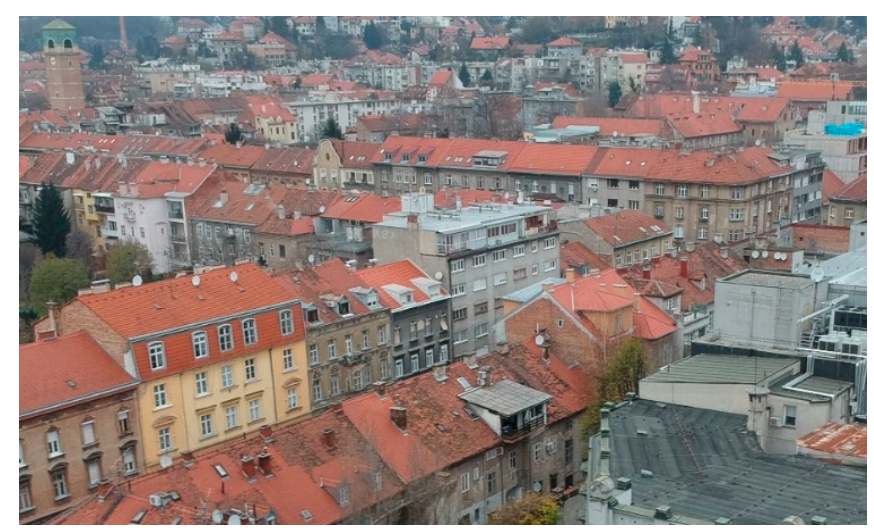

(b)

Figure 6. (a) Reconstruction works in urban areas_-building of new facilities which directly influence the seismic safety of existing structures. (b) Typical street in the old city of Zagreb, where the majority of buildings are made of masonry (photos by M. Stepinac). 


\section{Open Challenges in the Framework of the ARES Project}

The preservation of the building stock tackles societal challenges, environmental issues, and resource efficiency and represents the complex process of engineering and technical work.

The broad range of available methods shows the extensive experience in the measurement techniques gained in recent years. However, this experience, so far, has not led to a considerable advance in the quality of assessment with regard to the evaluation of the reliability of structures. Most methods only allow for the determination of the level of degradation and the localization of damages or the determination of localized material properties that do not represent the overall properties and load-carrying capacity of the entire structure. So far, it is often not possible to relate and interpret these measurements with regard to strength and stiffness properties required for the design and evaluation of reliability of the structure with sufficient certainty. Advanced methods for the assessment and probabilistic evaluation of existing structures make use of updated information and are already successfully applied in different other fields [51] but are still scarce in masonry engineering [29,52-56].

At the moment, there is a huge knowledge gap in the assessment methods and design checks of existing structures. Without appropriate guidelines, it is difficult to approach the problem, and this often leads to the wrong interpretation of collected data, and, thus, wrong decision scenarios for the reinforcement and rehabilitation of existing structures. The development of investigation techniques for the updating of material properties will help in reducing the uncertainty associated with the prediction of the structural behaviour of existing structures.

The ARES project, in this context, currently tries to fill the mentioned gaps. The project is financially supported by the Croatian Science Foundation and aims at delivering the basis for advanced assessment and design of existing structures, allowing a more economic design and a more accurate analysis of the consequences of failure. The ARES project aims to improve the way assessment is actually carried out. Standard methods will be compared, and necessary procedures will be determined to simplify assessment for practical use. General guidelines will also be developed, and safety factors will be reviewed.

The research project will provide knowledge about the building stock in Croatia, assessment of existing masonry structures and prediction of material properties from NDT. In addition, one of the current project goals is to evaluate updating methods of properties for the application of the assessment and verification methods for structures, including consideration of time-dependent behaviour and the influence of environmental conditions.

Furthermore, it is expected that in the current revision of the Eurocodes the consideration of existing structures will be more prominent, but, so far, no adequate international rules for the assessment, reuse and rehabilitation of existing structures exist.

In the most developed societies, as they progress, the feeling grows that it is necessary to maintain the existing building stock to preserve cultural identities. Preserving old buildings also benefits businesses and the local economy of societies. Preservation reduces waste, demolition energy use and new construction. Adaptive re-use concepts, renovations for less energy use, maintenance and type of use also affect building sustainability.

The following main challenges for future research and development in the field of assessment of existing structures can be identified:

- efficient determination of properties of structures

- $\quad$ precise prediction of material properties

- reliable prediction of the structural performance

- accounting for updated information in the assessment process

- optimization of verification and design procedures

- quantification of the impact of loading history and load duration on the load-carrying capacity in the remaining service life

- development of low invasive measures for intervention and rehabilitation 
- enhancement of the communication with decision-makers.

Solving the above-mentioned issues can be of valuable use and precious help for consultants and designers, as well as for researchers and scholars dealing with the assessment of masonry structures.

\section{Conclusions}

European building stock comprises a large number of masonry structures which are vulnerable to seismic excitation. To reduce vulnerability, they usually need to be strengthened with either steel or non-metallic reinforcement. Configuration and the amount or reinforcement need to be determined after the assessment is done. Since sustainability is becoming a prevailing issue, the general aim seems to be shifting from building new structures to the maintenance of existing ones. Thus, the evaluation of structural behaviour and strengthening techniques is becoming more important than it was before. Many questions regarding seismic vulnerability assessment of masonry structures remain unanswered, although many tools and techniques for estimation of material properties exist. Most of the historic structures and a lot of residential buildings are built with masonry, so both economic and cultural aspects are at risk. In many cases, access to the interior of a structure is limited. At the same time, energy efficiency is currently being improved in a lot of structures without any seismic or even structural considerations. Some simple solutions may lead to a large improvement in seismic behaviour, such as adding horizontal steel rods to ensure a box-type behaviour of a structure.

The majority of existing design standards regulate the design of new structures but provide poor information for their maintenance and repair. Although some guidelines and technical documents exist, they need to be improved and adapted to different solutions. Further research on material properties (and also its variability), risk assessment and modelling is, hence, necessary. Although there is a lot of experience regarding existing structures, no significant advancement in the quality of assessment can actually be perceived. The interpretation of measurements and their relation to calculation parameters still represents a weak aspect of the overall process. Currently, there is a huge knowledge gap, especially in the assessment methods and design checks for existing structures, in every aspect of the assessment process.

Firstly, it is important to clearly define which parameters must be tested, and which may be calculated (i.e., is it necessary to measure mortar characteristics or are they similar for the Croatian building stock? Is it necessary to measure shear strength or will the well-known expressions approximate the values appropriately?). In this regard, the plan is to make case studies on existing structures to develop the exact procedure.

Secondly, the focus should be spent on how to properly model such a series of structures, considering economy. This is in contrast with the current practice for existing structures, which is usually either overly complex or overly simplified. The plan is thus to model structures with different input parameters, and afterwards try to assess them before testing. The values will be compared to the ones provided by tests and models will be calibrated. The procedure will be repeated until a stable system (i.e., where no further calibration is needed) will be obtained.

Thirdly, gaps exist in the way strengthening is ensured (which safety factors can be expected for a specific strengthening technique, masonry and standard practice characteristic of Croatia? How does strengthening influence the parameters for modelling? etc.).

The ARES project, in this context, tries to fill these gaps, allowing for a more economic design and a more accurate analysis of the consequences of failure. In order to achieve sustainability, SHM should be implemented to ensure continuous tracking of structural behaviour and provide owners with information important for maintenance.

Author Contributions: Conceptualization, M.S. and C.B.; methodology, M.S., C.B. and T.K.; validation, M.S. and T.K.; formal analysis, M.S., T.R. and I.H.; investigation, M.S., T.R. and I.H.; resources, M.S., C.B., T.R. and I.H.; photo credit, M.S.; writing-original draft preparation, M.S. and T.R.; writing—review and editing, M.S., C.B.; visualization, M.S. and I.H.; supervision, M.S. and T.K.; project administration, M.S.; funding acquisition, M.S. All authors have read and agreed to the published version of the manuscript. 
Funding: This research was funded by Croatian Science Foundation, grant number UIP-2019-04-3749.

Conflicts of Interest: The authors declare no conflict of interest. The funders had no role in the design of the study; in the collection, analyses, or interpretation of data; in the writing of the manuscript, or in the decision to publish the results.

\section{References}

1. Negro, P.; Mola, E. A Performance Based Approach for the Seismic Assessment and Rehabilitation of Existing RC Buildings. Bull. Earthq. Eng. 2017. [CrossRef]

2. Barbieri, G.; Biolzi, L.; Bocciarelli, M.; Fregonese, L.; Frigeri, A. Assessing the Seismic Vulnerability of a Historical Building. Eng. Struct. 2013, 57, 523-535. [CrossRef]

3. Papathoma-Köhle, M. Vulnerability Curves vs. Vulnerability Indicators: Application of an Indicator-Based Methodology for Debris-Flow Hazards. Nat. Hazards Earth Syst. Sci. 2016. [CrossRef]

4. Goretti, A.; Di Pasquale, G. An Overview of Post-Earthquake Damage Assessment in Italy. In EERI Invitational Workshop an Action Plan to Develop Earthquake Damage and Loss Data Protocols; Earthquake Engineering Research Institute: Oakland, CA, USA, 2002.

5. Lourenco, P.; Karanikoloudis, G. Seismic Behavior and Assessment of Masonry Heritage Structures. Needs in Engineering Judgement and Education. RILEM Tech. Lett. 2019. [CrossRef]

6. Republic of Croatia Ministry of Construction and Physical Planning. Proposal of the Long-Term Strategy for Mobilising Investment in the Renovation of the National Building Stock of the Republic of Croatia; National Renovation Report; Ministry of Construction and Physical Planning: Zagreb, Croatia, 2014.

7. Sigmund, Z.; Radujkovic, M.; Lazarevic, D. Decision Support Model for Seismic Strengthening Technology Selection of Masonry Buildings. Teh. Vjesn. Tech. Gaz. 2016, 23, 791-800. [CrossRef]

8. Dietsch, P.; Kreuzinger, H. Guideline on the Assessment of Timber Structures: Summary. Eng. Struct. 2011. [CrossRef]

9. Steiger, R.; Kohler, J. Development of New Swiss Standards for the Reassessment of Existing Load Bearing Structures. In Proceedings of the 41th Meeting, International Council for Research and Innovation in Building and Construction, Working Commission W18 - Timber Structures, CIB-W18 Meeting 41, Paper No. 41-102-2; St. Andrews-by-the-Sea, Canada; University of Karlsruhe: Karlsruhe, Germany, 2008.

10. Diamantidis, D. Reiability assessment of existing structures. Eng. Struct. 1987, 9, 177-182. [CrossRef]

11. ISO 2394:2015: General Principles on Reliability for Structures; ISO: Geneva, Switzerland, 2015. [CrossRef]

12. JCSS. Probabilistic Model Code; Joint Committee on Structural Safety (JCSS): Zurich, Swotzerland, 2001; ISBN 978-3-909386-79-6.

13. ISO 13822. Bases for Design of Structures-Assessment of Existing Structures; ISO: Geneva, Switzerland, 2010.

14. SIA. SIA-Richtlinie 462: Beurteilung Der Tragsicherheit Bestehender Bauwerke (Guideline SIA 462: Assessment of the Structural Safety of Existing Buildings); SIA: Zurich, Switzerland, 1994.

15. NEN 8700: Assessment of Existing Structures in Case of Reconstruction and Disapproval—Basic Rules; NEN: Delft, The Netherlands, 2011.

16. SIA-Norm 469: Erhaltung von Bauwerken (Standard SIA 469: Maintenance of Buildings); SIA: Zurich, Switzerland, 1997.

17. EN 1998-3-Eurocode 8: Design of Structures for Earthquake Resistance_Part 3: Assessment and Retrofitting of Buildings; CEN: Brussels, Belgium, 2004.

18. Derakhshan, H. Proposed Update to Masonry Provisions of ASCE/SEI 41: Seismic Evaluation and Retrofit of Existing Buildings. In Proceedings of the 15th World Conference Earthquake Engineering, Lisbon, Portugal, 24-28 September 2012.

19. Pekelnicky, R.; Poland, C. ASCE 41-13: Seismic Evaluation and Retrofit Rehabilitation of Existing Buildings. In SEAOC 2012 Convention Proceedings, Santa Fe, New Mexico; Structural Engineers Association of California (SEAOC): Sacramento, CA, USA, 2012; 12p.

20. ASTM C1197-14a. Standard Test Method for In Situ Measurement of Masonry Deformability Properties Using the Flatjack Method; ASTM International: West Conshohocken, PA, USA, 2014.

21. ASTM C1587/C1587M-15. Standard Practice for Preparation of Field Removed Manufactured Masonry Units and Masonry Specimens for Testing; ASTM International: West Conshohocken, PA, USA, 2015. 
22. ASTM C1531-16. Standard Test Methods for In Situ Measurement of Masonry Mortar Joint Shear Strength Index; ASTM International: West Conshohocken, PA, USA, 2016.

23. ASTM C1532/C1532M-19a. Standard Practice for Selection, Removal, and Shipment of Manufactured Masonry Units and Masonry Specimens from Existing Construction; ASTM International: West Conshohocken, PA, USA, 2019.

24. ASTM C1196-14a. Standard Test Method for in situ Compressive Stress within Solid Unit Masonry Estimated Using Flatjack Measurements; ASTM International: West Conshohocken, PA, USA, 2014.

25. ASTM C1019-19. Standard Test Method for Sampling and Testing Grout for Masonry; ASTM International: West Conshohocken, PA, USA, 2019.

26. Dymiotis, C.; Gutlederer, B.M. Allowing for Uncertainties in the Modelling of Masonry Compressive Strength. Constr. Build. Mater. 2002, 16, 443-452. [CrossRef]

27. Borri, A.; Corradi, M.; De Maria, A.; Sisti, R. Calibration of a Visual Method for the Analysis of the Mechanical Properties of Historic Masonry. Procedia Struct. Integr. 2018, 11, 418-427. [CrossRef]

28. Breysse, D.; Martínez-Fernández, J.L. Assessing Concrete Strength with Rebound Hammer: Review of Key Issues and Ideas for More Reliable Conclusions. Mater. Struct. Constr. 2014, 47, 1589-1604. [CrossRef]

29. Sýkora, M.; Diamantidis, D.; Holický, M.; Marková, J.; Rózsás, Á. Assessment of Compressive Strength of Historic Masonry Using Non-Destructive and Destructive Techniques. Constr. Build. Mater. 2018, 193, 196-210. [CrossRef]

30. Agred, K.; Klysz, G.; Balayssac, J.P. Location of Reinforcement and Moisture Assessment in Reinforced Concrete with a Double Receiver GPR Antenna. Constr. Build. Mater. 2018, 188, 1119-1127. [CrossRef]

31. Sajid, S.H.; Ali, S.M.; Carino, N.J.; Saeed, S.; Sajid, H.U.; Chouinard, L. Strength Estimation of Concrete Masonry Units Using Stress-Wave Methods. Constr. Build. Mater. 2018, 163, 518-528. [CrossRef]

32. Mesquita, E.; Martini, R.; Alves, A.; Antunes, P.; Varum, H. Non-Destructive Characterization of Ancient Clay Brick Walls by Indirect Ultrasonic Measurements. J. Build. Eng. 2018, 19, 172-180. [CrossRef]

33. Martini, R.; Carvalho, J.; Barraca, N.; Arêde, A.; Varum, H. Advances on the Use of Non-Destructive Techniques for Mechanical Characterization of Stone Masonry: GPR and Sonic Tests. Procedia Struct. Integr. 2017, 5, 1108-1115. [CrossRef]

34. Valluzzi, M.R.; Cescatti, E.; Cardani, G.; Cantini, L.; Zanzi, L.; Colla, C.; Casarin, F. Calibration of Sonic Pulse Velocity Tests for Detection of Variable Conditions in Masonry Walls. Constr. Build. Mater. 2018, 192, 272-286. [CrossRef]

35. Wai-Lok Lai, W.; Dérobert, X.; Annan, P. A Review of Ground Penetrating Radar Application in Civil Engineering: A 30-Year Journey from Locating and Testing to Imaging and Diagnosis. NDT E Int. 2018, 96, 58-78. [CrossRef]

36. Meola, C. Infrared Thermography of Masonry Structures. Infrared Phys. Technol. 2007, 49, 228-233. [CrossRef]

37. Schuller, M.P. Nondestructive Testing and Damage Assessment of Masonry Structures. Prog. Struct. Eng. Mater. 2003, 5, 239-251. [CrossRef]

38. Parivallal, S.; Kesavan, K.; Ravisankar, K.; Sundram, B.A.; Ahmed, A.K.F. Evaluation of In-Situ Stress in Masonry Structures by Flat Jack Technique. Natl. Semin. Exhib. Non-Destr. Eval. 2011, 2011, 8-13.

39. Simões, A.; Gago, A.; Bento, R.; Lopes, M. Flat-Jack Tests on Old Masonry Buildings. In Proceedings of the 15th International Conference Experimental Mechanics, Porto, Portugal, 22-27 July 2012; Volume 1, p. 3056.

40. Łatka, D.; Matysek, P. The Estimation of Compressive Stress Level in Brick Masonry Using the Flat-Jack Method. Procedia Eng. 2017, 193, 266-272. [CrossRef]

41. Croce, P.; Beconcini, M.L.; Formichi, P.; Cioni, P.; Landi, F.; Mochi, C.; De Lellis, F.; Mariotti, E.; Serra, I. Shear Modulus of Masonry Walls: A Critical Review. Procedia Struct. Integr. 2018, 11, 339-346. [CrossRef]

42. Invernizzi, S.; Lacidogna, G.; Lozano-Ramírez, N.E.; Carpinteri, A. Structural Monitoring and Assessment of an Ancient Masonry Tower. Eng. Fract. Mech. 2018. [CrossRef]

43. Stepinac, M.; Rajčić, V.; Honfi, D. Condition Assessment of Timber Structures-Quantifying the Value of Information. In IABSE Symposium Nantes, 2018 Tomorrow's Megastructures International Association for Bridge and Structural Engineering; IABSE: Zurich, Switzerland, 2018.

44. Ramos, L.F.; De Roeck, G.; Lourenço, P.B.; Campos-Costa, A. Damage Identification on Arched Masonry Structures Using Ambient and Random Impact Vibrations. Eng. Struct. 2010. [CrossRef]

45. Mendes, N.; Lourenco, P.B. Seismic Assessment of Masonry Gaioleiro Buildings in Lisbon, Portugal. J. Earthq. Eng. 2010. [CrossRef] 
46. Grandić, I.Š.; Grandić, D. Estimation of Damage Severity Using Sparse Static Measurement. J. Civ. Eng. Manag. 2017, 23, 213-221. [CrossRef]

47. Mader, D.; Blaskow, R.; Westfeld, P.; Weller, C. Potential of UAV-Based Laser Scanner and Multispectral Camera Data in Building Inspection. Int. Arch. Photogramm. Remote Sens. Spat. Inf. Sci. 2016, 41. [CrossRef]

48. Ellenberg, A.; Kontsos, A.; Bartoli, I.; Pradhan, A. Masonry Crack Detection Application of an Unmanned Aerial Vehicle. In Proceedings of the 2014 International Conference on Computing in Civil and Building Engineering, Orlando, FL, USA, 23-25 June 2014. [CrossRef]

49. Atalić, J.; Šavor Novak, M.; Uroš, M. Seismic Risk for Croatia: Overview of Research Activities and Present Assessments with Guidelines for the Future. Građevinar 2019, 71, 923-947.

50. Beeson, S.; Kubin, J.; Unav, A.I. Potresna Osjetljivost Povijesnih Zidanih Konstrukcija Nepravilne Geometrije. Gradjevinar 2015, 67, 151-158. [CrossRef]

51. Rücker, P.W.; Hille, D.F.; Rohrmann, D.R. F08a Guideline for the Assessment of Existing Structures. SAMCO Final Rep. 2006, 48.

52. Holicky, M. Probabilistic Model for Masonry Strength. Eng. Mech. 2010, 17, 61-70.

53. Schueremans, L. Reliability Analysis in Structural Masonry Engineering 2. Local Probability of Failure of Masonry Shear Panels. Civ. Eng. 1995, 3, 553-568.

54. Vailati, M.; Monti, G.; Khazna, M.J.; Napoli, A.; Realfonzo, R. Probabilistic Assessment of Masonry Building Clusters. In Proceedings of the 15th World Conference Earthquake Engineering (WCEE), Lisbon, Portugal, 24-28 September 2012.

55. Asteris, P.G.; Moropoulou, A.; Skentou, A.D.; Apostolopoulou, M.; Mohebkhah, A.; Cavaleri, L.; Rodrigues, H.; Varum, H. Stochastic Vulnerability Assessment of Masonry Structures: Concepts, Modeling and Restoration Aspects. Appl. Sci. 2019, 9, 243. [CrossRef]

56. Rota, M.; Penna, A.; Magenes, G. A Framework for the Seismic Assessment of Existing Masonry Buildings Accounting for Different Sources of Uncertainty. Earthq. Eng. Struct. Dyn. 2014, 43, 1045-1066. [CrossRef]

(C) 2020 by the authors. Licensee MDPI, Basel, Switzerland. This article is an open access article distributed under the terms and conditions of the Creative Commons Attribution (CC BY) license (http://creativecommons.org/licenses/by/4.0/). 